\title{
ANALYSIS OF ISLAMIC ACCOUNTABILITY AND ISLAMIC GOVERNANCE IN ZAKAT INSTITUTION
}

\author{
Novendi Arkham Mubtadi \\ Faculty of Economics and Business, Universitas Peradaban
}

\begin{abstract}
Islamic accounting considers that accountability is perceived as a unity that can not be separated from one another. It makes a big difference to the basic goals of conventional accounting. Performance measurement is needed to ensure the company's operations in achieving its goals with the result that the need for Islamic governance in zakat institutions which is a good way of strength to run the process of managing an organization. The purpose of this study is to explain about Islamic governance and accountability of Islam in zakat institutions in Indonesia. This research uses qualitative method or conceptual study with descriptive-comparative study-analytical approach. The guidelines used in this study refers to the sharia enterprise theory in the conception of Islamic accountability's understanding as well as the zakat core principles to examine about Islamic governance.

The result of this research is the concept of Islamic accountability listed in sharia enterprise theory (hablumminallah, hablumminannas, and hablumminal'alam) can be seen from the presentation of financial statements in accordance with applicable accounting standards, the utilization of technology in financial reporting is by uploading financial statements on the regular website. While the concept of Islamic governance can be done by considering the number of supervisory commissions, the number of professionals in the supervisory commission, and the frequency of meetings with the supervisory commission. Recommendation for the next researcher is to conduct an empirical study on zakat institution related to Islamic accountability and Islamic governance.
\end{abstract}

Keywords: Islamic Accountability, Sharia Enterprise Theory, Islamic Governance, Zakat Core Principles

${ }^{*}$ Corresponding author's email: novendi_arkham@yahoo.co.id ISSN: 2549-3221 (Print) 2549-323X (Online)

DOI: $10.26487 /$ hebr.v3i1.1544 


\section{INTRODUCTION}

Islamic accounting considers that accountability is perceived as a unity that cannot be separated from one another. This is what makes a big difference with the basic goal of conventional accounting.Islamic accounting found that accountability is capable to serve as a liaison tool between stockholders, entities, and the public while still holding on accounting and Islamic values. This situation shows that Islamic accounting provides information according to real conditions, without any engineering from all parties, as a form of obedience to God, with the result that will create a good social relationship. Since Islamic accounting found the organization as an enterprise theory, which states that the survival of the organization is not only determined by the owner, but also the other contributing parties - workers, consumers, suppliers and accountants (Endahwati, 2014).

Furthermore, the need for Islamic governance in zakat which is a good way of strength to run the management process of an organization (Kaslam, 2007). The main foundation for a nonprofit organization such as an institution of zakat is the existence of a council that leads to good Islamic governance requirements until the decisionmaking process can be understood and implemented properly as well (UNDP, 1997).

In Indonesia, the management of zakat has been regulated under Law No. 38 of 1999 on zakat management by Decree of the Minister of Religious Affairs (KMA) 581 of 1999 regarding the implementation of Law No. 38 of 1999 and Decree of the Directorate General of Islamic Community Guidance and Hajj Affairs No.D / 291 of 2000 on thetechnical guidelines of Zakat management (Lestari, 2015). Then, followed by Law No. 23 of 2011 and Government Regulation No. 14 of 2014 on technical guidelines on zakat management in Indonesia (Asdiansyuri, 2016).

Therefore, need a comprehensive discussion related to Islamic accountability and Islamic governance at zakat institutions in Indonesia. The purpose of this study is to explain about Islamic governance and accountability of Islam in zakat institutions in Indonesia. In this case, which will be studied by the researcher in this study is including two things; first, what form of Islamic accountability in zakat institutions in Indonesia is, and secondly, what indicators that exist in Islamic governance are.

\section{LITERATURE REVIEW}

Ali (2015) describes accountability in the zakat perspective into two parts, which consists of primary accountability is responsibility to Allah SWT, and secondary accountability is responsibility to society. This concept is adapted from Mustaffha (2007) as follows:

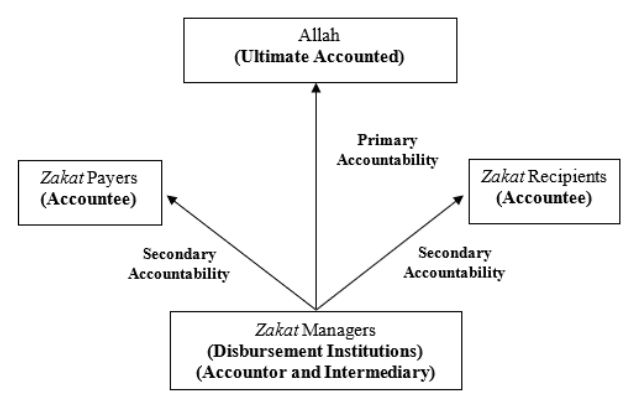

Figure 1. The Concept of Accountability That Underlying Zakat Disbursement Management by Zakat Institutions

Accountability can be done by presenting accountable and transparent statements of zakat. This report becomes strategy in order to increase accountability and transparency, so trust will arise from muzakki and stakeholders (Nikmatuniayah and Marliyati, 2015). Allah SWT says:

"Take, [O, Muhammad], from their 
wealth a charity by which you purify them and cause them increase, and invoke [ Allah 's blessings] upon them. Indeed, your invocations are reassurance for them. And Allah is Hearing and Knowing”. (QS At-Taubah: 103)

Based on the verse, it is explained that zakat was taken (invited) from the people who were obliged to pay zakat (muzakki) to be given to those who deserve it (mustahiq). Imam al-Qurthubi when interpreting the verse, explains that those who take and pick up zakat (amilin) officers, those who are assigned by the government to take, write down, calculate, and record the zakat from muzakki and given to mustahiq (Hafidhuddin, 2007: 125).

In measuring the efficiency and effectiveness of zakat management, BAZNAS and Bank Indonesia initiated the Zakat Core Principles (ZCP) concept which can serve as the guideline for zakat management not only in Indonesia but in the international world. Indonesia has uniquecharacteristicsin themanagement of zakat. In ZCP, Indonesia belongs to a country that embraces voluntary principles in the collection of zakat funds. And can be done by government agencies and non-government. Unlike the countries in the Middle East, Saudi Arabia, Sudan, Libya, Yemen, Kuwait, and Pakistan, which are mandatory and fully managed by the government. It can be seen in the following table:

Table 1. Characteristic of Zakat Management Scheme in Various Country

\begin{tabular}{cll}
\hline & \multicolumn{2}{c}{ Character of collection } \\
\cline { 2 - 3 } Full Government & \multicolumn{1}{c}{ Compulsory } & \multicolumn{1}{c}{ Voluntary } \\
& $\begin{array}{l}\text { Pakistan, Kuwait, } \\
\text { Yemen, Sudan, } \\
\text { Libya }\end{array}$ & $\begin{array}{l}\text { Bangladesh, Bah- } \\
\text { rain, Indonesia, } \\
\text { Jordan }\end{array}$ \\
\hline $\begin{array}{c}\text { Goverment } \\
\text { linked institution } \\
\text { (Corporation) }\end{array}$ & Malaysia & Singapore, Egypt \\
\hline
\end{tabular}

\begin{tabular}{cl}
\hline NGO - & Algeria, \\
& Indonesia, \\
& South Africa \\
\hline
\end{tabular}

Source: Beik et al (2014)

\section{RESEARCH METHODOLOGY}

This research uses qualitative method or conceptual study with descriptivecomparative study-analytical approach. The guidelines used in this study refers to the sharia enterprise theory in the conception of Islamic accountability's understanding as well as the zakat core principles to examine about Islamic governance. The method used in this study is a literature study with a conceptual study from book, journal, thesis, and dissertation.

\section{DISCUSSION}

1. Islamic Accountability at Zakat Institution In Indonesia

\section{a. Zakat Institution in Indonesia}

Rasulullah SAW once employed a young man from the Asad tribe, named Ibn Lutaibah, to take care of the zakat of Bani Sulaim. He also sent Ali ibn Abi Thalib and Muadz bin Jabal to Yemen to be amil zakat. Similarly, by the khulafaurrasyidin afterwards, they always have special officers who manage zakat, both taking and distributing. It indicates that zakat obligations are not merely charitable, but also an authoritative obligation (ijbari). Therefore, since the time of Rasulullah SAW until now, the management of zakat in almost every country is regulated by the government (Hafidhuddin, 2009: 169).

The history of zakat management in Indonesia by the government began in 1968. At a charity seminar organized by the Research and Workshop Faculty of Economics, Muhammadiah University of Jakarta, President Soeharto invites the community to carry out zakat in a concrete manner at the first time. After that, President Soeharto in a memorial 
speech of Isra Mi'raj at the state palace dated October 26, 1968 suggested the implementation of zakat more intensively to support the development of the country, and the President is ready to become a national zakat amil (Suyitno, 2005: 50).

In the development of the implementation of zakat in Indonesia, thereis a newtendencywhich is achangein the characteristics of the implementation of zakat. On May 29, 2002, the President inaugurated the national silaturrahmi and coordination meeting to I Badan Amil Zakat Nasional and Lembaga Amil Zakat throughout Indonesia at the State Palace. In his speech, the President emphasized that the Amil Zakat Agency either at the National or Regional level, or the Amil Zakat Institution to not hesitate in cooperation with the Minister of Religious Affairs, Minister of Finance, State Minister of Cooperatives and Small and Medium Enterprises as well as other related ministers. Then since the issuance of Law No. 38 of 1999 on the management of zakat, many institutions Amil Zakat (LAZ) are emerging. The phenomenon of the proliferation of LAZ, will further strengthen the social system toward civil society (Azhar and Karim, 2009).

The government has implemented the zakat amil standardization in 2013 to anticipate the negative things that may happen. This refers to Act No. 23 Year 2011 stating that the management of zakat is arranged with two models. First, the zakat management authority and provisions are regulated by the government, but in its implementation the government positions itself as a regulator and facilitator. Second, zakat management authority is given to the community, but it is required to coordinate, report and be prepared by the government. Both models will work well if zakat management organizations, both government and non-government, have good governance.

In general, in Act no. 23 of 2013, the Organization of Zakat Management in Indonesia is divided into two types:

- Badan Amil Zakat (BAZ), the Zakat Management Organization established by the government in charge of collecting, distributing zakat funds in accordance with the provisions outlined by sharia. BAZ consists of the Centre of National Amil Zakat Agency (BAZNAS) located in the state capital, Provincial BAZNAS, and Regency / City BAZNAS.

- Lembaga Amil Zakat (LAZ), the Zakat Management Organization established by the community with the approval of the government to collect and distribute zakat funds in accordance with the provisions outlined by sharia. The LAZ establishment shall be authorized by the Minister or the official appointed by the Minister. Thus, the position of LAZ is no longer equivalent to BAZ.

The existence of BAZ and LAZ is benefited by society.BAZ and LAZ are trying to help society's difficulties with its various programs.Various programs are implemented with the source of funding from zakat. For muzakki, the existence of BAZ and LAZ will be more helpful in zakat distribution to mustahiq and can keep riya 'or show off in front of mustahiq.For mustahiq its will reduce inferioritybefore muzakki.Although, there are still doubtful muzakki about the zakat distribution to the right by BAZ and LAZ. However, it can be overcome by providing good performance, as well as public accountability of the management of zakat funds with the result that muzakki believes to distribute his funds to the institution (Saidurrahman, 2013).

The BAZ must have Islamic accountability to the government and should supervise the Institute of Amil Zakat to avoid theillegal formation of LAZ and ensure that LAZ continues to provide periodic reports on the implementation 
of the shariah and financial audits, distribution and utilization that have been shari'a and financial audited to the BAZ.Each Badan Amil Zakat (BAZ) has a Zakat Management Unit (UPZ). In the Regulation of Badan Amil Zakat Nasional (PERBAZNAS) No. 2 Year 2016 on the Establishment and Working Procedures of Zakat Collecting Units, it is explained that UPZ must be legal entity and audited by public accountant.It shows that BAZNAS is very concerned about its accountability to make the stakeholders trust more to BAZNAS.

\section{b. Recipients of Zakat in Indonesia}

The word "innama" at the beginning of the verse of the surah taubah verse 60 means "hasyr" which means only or limited.The meaning of zakat is limited to eight classes in the verse.Then "lam" in the sentence "lilfuqoro" means "lam al milk" which means property, so it can be said zakat fund entirely belongs to the eighth asnaf.The eight asafs in the verse are two groups. The first group consists of four asnaf which begins with the word "lii" ie the poor, the poor, the amil, and muallaf (convert). The second group consists of the next four asnafs beginning with the word "fii" ie riqab, gharim, fi sabilillah, and ibn sabil.The distribution of zakat to the first group means to be direct, or in other words consumptive. While the distribution of zakat to the second group can be indirect, means it can be used for certain purposes. For example, the provision of fixed assets or other facilities (Nadzri et al, 2012). The eight asnaf are among those who take zakat to meet their needs and some are taking it because of the needs of the Muslims against him. The needy, the poor, the gharim, riqab, and ibn sabil are the ones who take zakat to meet their needs. As for those who take zakat because the needs of the Muslims is amil and fi sabilillah (Dakhoir et al, 2014).
From the Quranic verses ordaining zakat (9: 60) as mentioned above, eight groups of beneficiaries have been identified and they consist of the following:

a) Masakeen - (the destitute), these are people who do not have anything, and who are in need of asking others for food, clothing and shelter.

b) Fuqaraa - (the poor or needy), these people have some money, but not sufficient for their everyday needs. The elderly are often amongst the 'fuqaraa'. The Prophet Muhammad said "He is not one of us who does not show tenderness to the young and who does not show respect to the elder." (At-Tirmidhi). It is a sad fact that the elderly tend to be neglected in today's society. According to recent research, older people are among the most excluded and materially worse off. The definition of masakeen and fuqaraa is based on the Hanafi school while Shafii school has the opposite definition.

c) Amil Zakat - these are the people whom are authorized to manage zakat. The Quran has given them the right to receive a fee for their work (maximum one-eighth), which includes collecting, recording, guarding, dividing and distributing zakat. The government may add or reduce the amount of the fee based on actual fund needed and prevailing regulation.

d) Fi sabilillah - this means 'in the path of Allah' and pertains to anyone struggling for a righteous cause, including expenditure towards the promotion of Islam and for all charitable purposes.

e) Gharimun - these are the debtors, people burdened by debts because of personal needs or social necessity with condition that these debts are permitted by the Shari'ah. These people should be given zakat if they do not have enough money beyond their basic needs to repay debts. Help should also be provided to 
those who may have landed themselves in debt as a result of social obligations such as supporting an orphan or renovating a school.

f) Ibnu Sabil - the wayfarers are the travelers facing shortage of money. These people can receive zakat, if the purpose for travelling is lawful. In contemporary situation, refugees or displaced people may fall under this category.

g) Riqab - the riqab are people in bondage or slavery. Zakat can be used to buy the freedom of such a person. In current circumstances, it would be very difficult to find the slaves as practiced in the past and as discussed in the classical literature. However, Yusuf Al Qaradawi is of the view that people or country that are under foreign occupation may be categorized as slave in modern times and hence, eligible to receive zakat under this asnaf. Economic slavery such as trapped protistutions and oppressive conditions in modern times can be categorised under this category of 'ashnaf.

h) Mu'allaf - translated literally as 'those who have converted to Islam'. Shafii school have limited the status of 'newly convert' to maximum two years. However, majority of schools agree to include the non Muslim, who do not against the Muslim and whose circumstances are so desperate, as part of this asnaf. It may attract their hearts closer to Islam.

There are some differences in the interpretation of verses pertaining to mustahiq in different countries. For example in Brunei Darussalam, only acknowledge six asnafs other than riqab and fi sabilillah. This is because in Brunei Darussalam, the word fi sabilillah experiencing mudhayyiqin (narrowing meaning) that means people who fight in the physical battlefield to defend Islam so that such a person cannot be found anymore in the present day. Unlike in Malaysia, the word fi sabilillah experienced muwassain (extension of meaning) that is all kinds of goodness that is in the way of Allah, for example giving of revolving fund, building of mosque, etc. This is because Malaysia uses the general approach of umm al-balwa (something that is already common). While Indonesia, using the rules of tafriqul halal 'anil haram (separating something kosher from the haram) so that the scholars, in this case the National Sharia Council, agreed interpret the fi sabilillah limited in education and da'wah only. For example scholarship grants and cadre of scholars.

\section{c. Forms of Islamic} Accountability At Zakat Institution

Understanding Islamic accountability in Islamic accounting has a more complex form of accountability, that is, organizational managers are responsible not only to owners, but also to stakeholders, socially responsible, responsible to nature, and accountable to God. This theory is often known as sharia enterprise theory (Triyuwono, 2003).

Accountability within the framework of agency relationships between principals and agents often experiences the disharmony of opportunistic behaviors on the part of agents that are a form of egoistic, materialistic, and utilitarian nature. Some agents act for their personal interests, not for the principal's interests. This is where the role of accounting is required as a means of accountability agent to the principal (Rahmayati, 2015).

Huda and Suwardjuwono (2013) have identified the accountability issues faced by OPZ. The results of the research indicate the overlapping of OPZ empowerment program, inappropriate of muzakki and mustahiq data, limited OPZ partnership, government policy is against the program of empowerment, no cheap promotional model, and the limited professional amil. 
Islamic accountability can be done by presenting accountable and transparent statements of zakat. This report becomes strategic in order to improve accountability and transparency, so that will arise the trust of muzakki and stakeholders (Nikamatuniayah and Marliyati, 2015).

Islamic accountability in the management of zakat has been proven empirically in a study on the Institute of Amil Zakat, Infak, Shadaqah Muhammadiyah (LAZISMU) Sidoarjo (Hermawan and Rini, 2016). The object of the case study has applied Islamic accountability values as the basis for its financial reporting. This can be seen from the allocation of zakat funds in 2015 which has been issued is the contribution to Allah SWT of Rp 2,500,000.00, contribution to direct stakeholders of Rp 3,400,000.00, contribution to indirect stakeholders of $\mathrm{Rp}$ 7.900.000,00 and contribution to nature of $\mathrm{Rp}$ 2.000.000,00. The development of the concept in accountability of Islam is also increasingly developed with the addition of existing concepts that is hablum minallah, hablum minannas, and hablum minal'alam, with a new concept that is the concept of halal ownership (Suwito et al, 2016).

\section{Islamic Governance At Zakat Institution In Indonesia}

Zakat management consists of two main activities of collection and distribution (Oran, 2009). Mustaffha (2007) argues that in the distribution of zakat must be more careful because the distribution is clearly regulated in the Qur'an. This is an important concern for amil zakat carrying out the mandate as stated in the Law on Zakat Management No. 23 of 2011 (Rusydiana and Al-Farisi, 2016). Therefore, management of zakat management must uphold the principles of accountability, transparency, and professionalism. This includes the need for efficiency and effectiveness (Beik et al, 2014). In measuring the efficiency and effectiveness of zakat management, BAZNAS and Bank Indonesia initiated the Zakat Core Principles (ZCP) concept which can serve as the guideline for zakat management not only in Indonesia but in the international world.

Zakat is a maliyah ijtimaiyyah service that has a strategic importance both in terms of teaching and development of the economic welfare of the ummah. Thus, zakat is a manifestation of faith in God and a manifestation of care to others in terms of solving socioeconomic problems such as income gap, unemployment, and poverty alleviation. This can be done through optimizing the distribution of zakat funds efficiently (Anwar, 2012).

These conditions can be achieved through zakat governance effectively and professionally. Governance is defined as the decision-making process and how the process is implemented. Good governance is the key for an organization to achieve its goals. Therefore, in zakat management organizations, amil must have good governance principles that are transparent and accountable in disclosing information in general to stakeholders and the public.

Zakat Core Principles (ZCP) clearly discusses zakat governance issues that are oriented towards Good Amil Governance (GAG). ZCP refers to many of the Basel Core Principles (BCP) that govern the core principles of banking. This matter, related to regulation, can be seen in following table:

Table 2. The Comparison Between Basel Core Principles and Zakat Core Principles

\begin{tabular}{lll}
\hline Basel Core Princi- & Zakat Core Principles & $\begin{array}{l}\text { Dimen- } \\
\text { ples }\end{array}$ \\
(BCP) & ZCP of \\
(BCP) & & ZCP
\end{tabular}




\begin{tabular}{|c|c|c|c|c|c|}
\hline BCP 14 : & $\begin{array}{l}\text { Corpo- } \\
\text { rate Gov- } \\
\text { ernance }\end{array}$ & ZCP 8 : & $\begin{array}{l}\text { Good } \\
\text { Amil } \\
\text { Gover- } \\
\text { nance }\end{array}$ & $\begin{array}{l}\text { Zakat } \\
\text { Gover- } \\
\text { nance }\end{array}$ & $\begin{array}{lll}\text { ZCP 28: } & \text { Disclo- } & \text { Shariah } \\
& \text { sure and } & \text { Gover- } \\
\text { Trans- } & \text { nance } \\
\text { parency } & \end{array}$ \\
\hline BCP 15 : & $\begin{array}{l}\text { Risk } \\
\text { Man- } \\
\text { agement } \\
\text { Process }\end{array}$ & & & & $\begin{array}{ccc}\text { Abuse of } & \text { ZCP 29: } & \text { Abuse of } \\
\text { Financial } & & \text { Zakat } \\
\text { Ser- } & & \text { Ser- } \\
\text { vices } & & \text { vices } \\
\end{array}$ \\
\hline ВCP 16 : & $\begin{array}{l}\text { Capital } \\
\text { Adequacy }\end{array}$ & ZCP 9: & $\begin{array}{l}\text { Col- } \\
\text { lection } \\
\text { Manage- } \\
\text { ment }\end{array}$ & & $\begin{array}{l}\text { Source: Beik et al (2014) } \\
\text { In governance is often found the term }\end{array}$ \\
\hline BCP 17 : & $\begin{array}{l}\text { Credit } \\
\text { Risk }\end{array}$ & & & & $\begin{array}{l}\text { one-tier system and two-tier system. } \\
\text { One-tier system is widely used in anglo- }\end{array}$ \\
\hline ВСР 18 : & $\begin{array}{l}\text { Problem } \\
\text { Assets, } \\
\text { Provi- } \\
\text { sion, and } \\
\text { Reserves }\end{array}$ & & & & $\begin{array}{l}\text { saxon countries such as the United } \\
\text { States, Britain, Canada and Australia. } \\
\text { While the two-tier system is widely used } \\
\text { in mainland European countries such as }\end{array}$ \\
\hline BCP 19： & $\begin{array}{l}\text { Concen- } \\
\text { tration } \\
\text { Risk, and } \\
\text { Large } \\
\text { Exposure } \\
\text { Limits }\end{array}$ & ZCP 10 : & $\begin{array}{l}\text { Disburse- } \\
\text { ment } \\
\text { Manage- } \\
\text { ment }\end{array}$ & $\begin{array}{l}\text { Interme- } \\
\text { diary } \\
\text { Function }\end{array}$ & $\begin{array}{l}\text { Germany and the Netherlands. Indonesia } \\
\text { includes a two-tier system (FCGI, 2000). } \\
\text { In a one-tier system, the roles of the } \\
\text { board of commissioners (supervisors) }\end{array}$ \\
\hline $\begin{array}{l}\mathrm{BCP} \\
20:\end{array}$ & $\begin{array}{l}\text { Transac- } \\
\text { tion with } \\
\text { Related } \\
\text { Parties }\end{array}$ & & & & $\begin{array}{l}\text { and the role of the board of directors } \\
\text { (executors/executives) are made in } \\
\text { one container. This unification makes }\end{array}$ \\
\hline BCP 21 : & $\begin{array}{l}\text { Coun- } \\
\text { try and } \\
\text { Transfer } \\
\text { Risk }\end{array}$ & ZCP 11: & $\begin{array}{l}\text { Country } \\
\text { and } \\
\text { Transfer } \\
\text { Risk }\end{array}$ & & $\begin{array}{l}\text { unclear the role of supervisors and } \\
\text { executors. While in the two-tier system, } \\
\text { the roles of the board of commissioners }\end{array}$ \\
\hline $\begin{array}{l}\mathrm{BCP} \\
22:\end{array}$ & $\begin{array}{l}\text { Market } \\
\text { Risk }\end{array}$ & ZCP 12 : & $\begin{array}{l}\text { Repution } \\
\text { Muzakki } \\
\text { Loss Risk }\end{array}$ & & $\begin{array}{l}\text { and the board of directors are clearly } \\
\text { separated. The board of commissioners } \\
\text { will oversee the work of the board of }\end{array}$ \\
\hline $\begin{array}{l}\mathrm{BCP} \\
23:\end{array}$ & $\begin{array}{l}\text { Interest } \\
\text { Risk } \\
\text { in The } \\
\text { Banking }\end{array}$ & - & & $\begin{array}{l}\text { Risk } \\
\text { Manage- } \\
\text { ment }\end{array}$ & $\begin{array}{l}\text { directors (Tricker, 2009). } \\
\text { In a one-tier governance system, there } \\
\text { are four types of board structures: }\end{array}$ \\
\hline & Book & & & & a. All the executive directors are \\
\hline $\begin{array}{l}\mathrm{BCP} \\
24:\end{array}$ & $\begin{array}{l}\text { Liquidity } \\
\text { Risk }\end{array}$ & ZCP 13 : & $\begin{array}{l}\text { Disburse- } \\
\text { ment } \\
\text { Risk }\end{array}$ & & $\begin{array}{l}\text { board members. Top managers are also } \\
\text { board members. This is mostly found in }\end{array}$ \\
\hline $\begin{array}{l}\mathrm{BCP} \\
25:\end{array}$ & $\begin{array}{l}\text { Oper- } \\
\text { ational } \\
\text { Risk }\end{array}$ & ZCP 14: & $\begin{array}{l}\text { Oper- } \\
\text { ational } \\
\text { Risk }\end{array}$ & & $\begin{array}{l}\text { small companies, family companies and } \\
\text { start-up business. } \\
\text { b. The majority of board members }\end{array}$ \\
\hline $\begin{array}{l}\mathrm{BCP} \\
26:\end{array}$ & $\begin{array}{l}\text { Internal } \\
\text { Control } \\
\text { and } \\
\text { Audit }\end{array}$ & ZCP 15 : & $\begin{array}{l}\text { Shariah } \\
\text { Control } \\
\text { and } \\
\text { Internal }\end{array}$ & & $\begin{array}{l}\text { are executive directors. In this structure } \\
\text { there are non-executive directors in } \\
\text { the board but the numbers are few }\end{array}$ \\
\hline $\begin{array}{l}\mathrm{BCP} \\
27:\end{array}$ & $\begin{array}{l}\text { Financial } \\
\text { Report- } \\
\text { ing } \\
\text { and } \\
\text { External } \\
\text { Audit }\end{array}$ & ZCP 27: & $\begin{array}{l}\text { Financial } \\
\text { Report- } \\
\text { ing and } \\
\text { External } \\
\text { Audit }\end{array}$ & & $\begin{array}{l}\text { (minority). } \\
\text { c. The majority are non-executive } \\
\text { directors. Most of these non-executive } \\
\text { directors are independent directors. } \\
\text { d. All non-executive directors are } \\
\text { board members. Many found in non- } \\
\text { profit organizations. This structure is }\end{array}$ \\
\hline
\end{tabular}


almost similar to a European two-tier structure.

For a two-tier governance system, this structure consists of two boards:

a. Supervisory board. It consists of independent non-executive directors and non-executive directors are not independent (connected).

b. Executive Board. It consists of all managing directors, such as CEO, CFO, $\mathrm{COO}$, CIO (C-level management).

Indonesia adheres to a two-tier governance system. This may be due to Dutch influence which also embraces the system. According to Hafidhuddin (2009: 183), in the format of amil zakat organization, the organizational structure of Badan Amil Zakat (BAZ) consists of Advisory Board (Dewan Pertimbangan), Supervisory Commission (Komisi Pengawas), and Implementing Agency (Badan Pelaksana). Zakat governance indicators, used in this study, will be measured based on the framework of Wahab (2013) that is board size, professional on board, and frequency of board meetings.

a. Board size

Zakat is a religious obligation, it is appropriate that the manager of zakat has a paradigm that what they do is a form of worship and even jihad fi sabilillah. Rasulullah SAW said:

"Amil alms (zakat) working on the foundation of Al-Haq is like a soldier of fi sabilillah so he returns to his house." (Abu Dawud, Tirmidhi, Ibn Majah, Ibn Khuzaimah, and Imam Hakim)

From the hadith it can be deduced that people who want to be zakat officers will get a great reward even as the people who fight in the way of Allah SWT. Therefore, how noble the degree of amiliin if they carry out their duties with a mandate.

The number of boards has an important role in determining policy and decision making relating to the performance of an organization (FCGI, 2000). The size of a large council will be more effective in providing critical ideas to ensure OPZ operations are more organized and well organized, or in other words will enhance efficiency. A large number of boards will be more useful in the efficiency of an organization's performance (Goodstein et al, 1994). The large size of the board with a variety of competencies will help in ensuring the resources as well as reducing the uncertainty of the work environment. Although coordination, communication, and decision-making will be a powerful barrier to an organization's financial performance as the number of boards increases (Tanna et al, 2004).

\section{b. Professional on board}

Based on the Surah Yusuf verse 55, explained that to occupy a profession, a person must be accountable to have professionalism. In the fiqh literature, the requirement to be the manager of zakat should at least: Muslims, mukallaf (akil baligh), trust, understand and well understand the laws in the sector of zakat, and understand the work done with full responsibility.

The management of zakat professionally requires skilled personnel, mastering the issues related to zakat, dedication, honest and trust. It is inconceivable that zakat managers do not control zakat-related matters, such as muzakki, nisab, haul and mustahiq zakat. It is also difficult to imagine if zakat managers are not dedicated, work lillahi ta'ala. Moreover, if the manager of zakat is not honest and trustworthy. The possibility that will happen is zakat not up to mustahiq, and may also only be used for personal interests only. Therefore, skilled personnel, mastering issues related to zakat, honest and trust is urgently needed in a professional zakat management system. Threats to unprofessional managers of zakat are clearly stated in a following hadith:

"If the message is wasted, then wait 
for the moment of destruction. Abu Hurairah asked: How is the message wasted O Messenger of Allah, he replied: If a business is left to a person who is not an expert. "(Narrated by Imam Bukhari)

Good zakat mechanisms, increasing people's purchasing power can still be stable. Then zakat has a significant role to maintain economic stability. But all that does not feel maximal, if the board of directors who take care of zakat management in zakat institution is not a professional person. There will be problems both on the collection and efficiency of the distribution (Nurzaman, 2010).

c. Frequency of Board Meetings

Ali ibn Thalib once said: "It will not break anything because of deliberation."

Then Shaykh Ja'far As Sadiq once told Syaufan Ats Tsauri: "Conquer your business with those who fear God."

The more frequent meetings of the board will improve the operational performance of an organization (Vafeas, 1999). Board meetings are indeed needed in conditions and situations when the organization needs high control over an ongoing problem or error (Khancel, 2007).

The frequency of board meetings is measured by the number of meetings they make to improve the quality of governance and improve the efficiency level (Lin et al, 2009). But keep in mind, the effectiveness of the board in the meeting should be based on accountability to Allah SWT. In addition, with the allocation of time for the board in meetings will give them the opportunity to conduct oversight and review on the performance of the organization.

\section{CONCLUSION}

Islamic accountability in zakat institutions is required for professional management of zakat to be achieved. Some forms of accountability of Islam in question include understanding the concept of accountability listed in sharia enterprise theory that is hablumminallah, hablumminannas, and hablumminanl'alam, presenting financial statements in accordance with applicable accounting standards, and utilizing technology in reporting by uploading financial statements on the website regularly to get the public information needed. Islamic governance as set forth in zakat core principles is taking into account board size, professional on board, and frequency of boardmeetings is the key for zakat institutions in every policy to be taken.

The suggestions that can be put forward for the next researcher is to conduct a more in-depth analysis of whether there is a direction of influence of Islamic governance on Islamic accountability by conducting an empirical study on the institution of zakat. Canalso usequalitative methods by conducting interviews with zakat institution management.

\section{REFERENCES}

Aan Slamet Rusydiana dan Salman AlFarisi. 2016. The Efficiency of Zakah Institutions Using Data Envelopment Analysis. AL-IQTISHAD Jurnal of Islamic Economics, Vol.8, No.2, Hal.213-226

Achmad Syaiful Hidayat Anwar. 2012. Model Tata Kelola Badan dan Lembaga Amil Zakat Sebagai Upaya Untuk Meningkatkan Pemberdayaan Ekonomi Masyarakat (Studi pada Badan/Lembaga Amil Zakat di Kota Malang). Jurnal Humanity, Vol.7, No.2, Hal.1-13

Adiwarman Karim dan Azhar Syarief. 2009. Fenomena Unik Dibalik Menjamurnya Lembaga Amil Zakat di Indonesia. Zakat \& Empowering: Jurnal Pemikiran dan Gagasan, Vol.1

Alfi Lestari. 2015. Efisiensi Kinerja Keuangan Badan Amil Zakat Daerah 
: Pendekatan Data Envelopment Analysis. Jurnal Ekonomi dan Studi Pembangunan, Vol.16, No.2, Hal.177187

Ali, Nurul Nabilah Haji. 2015. The Influence of Governance to Zakat Disbursement Efficiency: Empirical Evidence from Brunei Darussalam. Tesis. Malaysia: International Islamic University Malaysia

Anim Rahmayati. 2015. Filantropi Islam: Model dan Akuntabilitas. Syariah Paper Accounting Fakultas Ekonomi Bisnis,Universitas Muhammadiyah Surakarta, Indonesia

Dakhoir, Ahmad, et al. 2014. The Construction of Law of Institutional The Management of Zakat Through Functions of Islamic Bankings Perspective Maqasid Al-Sharia. International Journal of Education and Research, Vol.2, No.5, Hal.89-98

Didin Hafidhuddin. 2007. Zakat dalam Perekonomian Modern. Jakarta: Gema Insani . 2009. Agar Harta Berkah dan Bertambah. Jakarta: Gema Insani

Forum for Corporate Governance in Indonesia (FCGI). 2000. Peranan Dewan Komisaris dan Komite Audit dalam Pelaksanaan Tata Kelola Perusahaan. Jakarta: FCGI

Goodstein, Jerry, et al. 1994. The Effect of Board Size and Diversity in Strategic Change. Strategic Management Journal, Vol. 15, Hal.241-250

Irfan Syauqi Beik, et al. 2014. Towards an Establishment of an Efficient and Sound Zakat System. Working Group of Zakat Core Principles

Iwan Triyuwono. 2003. Sinergi Oposisi Biner: Formulasi Tujuan Dasar Laporan Keuangan Akuntansi Syariah. AL-IQTISHAD Journal of Islamic Economics, Vol.4, No.1, Hal.79-90

Kaslam, Shawal. 2007. Governing Zakat as A Social Institution: The Malaysian
Perspective. Paper Presented at Zakat in South-East Asia, Padang, West Sumatera, Indonesia

Khanchel, Imam. 2007. Corporate Governance: Measurement and Determinant Analysis. Managerial Auditing Journal, Vol.22, No.8

Lin, C, et al. 2009. Corporate Governance and Firm Efficiency: Evidence from Chinas $\square$ s Publicly Listed Firms. Managerial and Decision Economics, Vol.30, No.3, Hal.193-209

Muhammad Soleh Nurzaman. 2010. Zakat and Human Development: An Emprical Analyis on Poverty Alleviation in Jakarta, Indonesia. Center for Islamic Economics and Finance, Qatar Faculty of Islamic Studies, Qatar Foundation

Mustaffha, Nazifah. 2007. Zakat Disbursement Efficiency: A Comparative Study of Zakat Institutions in Malaysia. Disertasi. Malaysia: International Islamic University Malaysia

Nadzri, Farah Aida Ahmad, et al. 2012. Zakat and Poverty Alleviation: Roles of Zakat Institutions in Malaysia. International Journal of Arts and Commerce, Vol.1, No.7, Hal.61-72

Nikmatuniayah, dan Marliyati. 2015. Akuntabilitas Laporan Keuangan Lembaga Amil Zakat.MIMBAR, Vol.31, No.2, Hal.485-494

Nurul Huda dan Tjiptohadi Suwarjuwono. 2013. Akuntabilitas Pengelolaan Zakat Melalui Pendekatan Modifikasi Action Research. Jurnal Akuntansi Multiparadigma, Vol.4, No.3, Hal.376-388

Oran, Ahmad F. 2009. Zakat Funds and Wealth Creation. Review of Islamic Economics, Vol.13, No.1, Hal.143-154 Saidurrahman. 2013. The Politics of Zakat Management in Indonesia: The Tension Between BAZ and LAZ. Journal of Indonesian Islam, Vol.2, No.2, Hal.366-382 
Sigit Hermawan dan Restu Widya Rini. 2016. Pengelolaan Dana Zakat, Infaq, dan Shadaqah Perspektif Sharia Enterprise Theory. Riset Akuntansi dan Keuangan Indonesia, Vol.1, No.1, Hal.12-24

Suwito, et al., 2016. Construction of Sharia Accounting, Zakat, Infaq, and Amal. Research Journal of Finance and Accounting, Vol.7, No.8, Hal.122-131

Suyitno. 2005. Anatomi Fiqh Zakat. Yogyakarta: Pustaka Pelajar

Tanna, S., et al. 2008. The Effect of Board Size and Composition of TheEfficiency of UK Banks. Economics, Finance, and Accounting Applied Research Working Paper Series, Conventry University Business School, United Kingdom

Tricker, Bob. 2009. Corporate Governance:Principles, Policies, and Practices. Oxford: Oxford University Press

Ulfiyani Asdiansyuri. 2016. Analisis PengaruhPengeluaranZakatterhadap Kesejahteraan Muzakki (Studi Kasus Pada BAZNAS Kabupaten Lombok Barat). International Journal of Social and Local Economic Governance, Vol.2, No.1, Hal.23-31

United Nations Development Programme (UNDP). 1997. Governance for Sustainable Human Development. UNDP Governance Policy Paper, New York, USA

Vafeas, Nikos. 1999. Board Meeting Frequency and Firm Performance. Journal of Financial Economics, Vol.53, No.1, Hal.113-142

Wahab, Norazlina Abdul. 2013. Efficiency and Governance of Zakat Institutions in Malaysia. Disertasi. Malaysia: International Islamic University Malaysia

Yosi Dian Endahwati. 2014. Akuntabilitas Pengelolaan Zakat, Infaq, dan Shadaqah. Jurnal Ilmiah Akuntansi dan Humanika, Vol.4, No.2 